\title{
O SIMBOLISMO DO BATISMO CAPTURADO EM CARTAS PARA PROFESSORES QUE MARCARAM: LEITURAS ENTRECRUZADAS
}

\author{
LÚCIA MARIA VAZ PERES
}

Universidade Federal de Pelotas

ALEXANDRE DA SILVA BORGES

Universidade Federal de Pelotas

\section{LUCIANA MARTINS TEIXEIRA LINDNER}

Universidade Federal de Pelotas

RESUMO Este trabalho é fruto do projeto de pesquisa denominado "Escrita de cartas aos professores que marcaram: memórias e imaginários ressonantes como fermentos de (auto)formação?" Visa problematizar as narrativas materializadas nas cartas, solicitadas para estudantes, em formação inicial em Pedagogia. Tendo o cunho epistolar como ferramenta empírica, optou-se pela análise simbólica à luz dos estudos teórico/metodológico do imaginário e dos estudos (auto)biográficos de formação. Ancorados em Josso (2002; 2010), Bachelard (1988; 1993), Durand (1988; 2008; 2012), Chevalier e Gheerbrant (2015) e Eliade (1977; 1992; 2013), a metodologia utilizada nessa investigação teve como base a pesquisa-formação e a mitocrítica, a partir dos referenciais construídos por Josso (2002), Delory-Momberguer (2008) e Durand (2012), respectivamente. Nosso foco foi buscar, nas recordações-referências, a amplificação da noção de professor-batismo, cuja imagem emergiu na simbólica das cartas analisadas.

Palavras-chave: Formação inicial de professores. Narrativas epistolares. Imaginário. Educação.

\section{ABSTRACT THE SYMBOLISM OF BAPTISM CAPTURED BY LETTERS WRITTEN TO TEACHERS WHO MADE A DIFFERENCE: INTERCROSSED READINGS}

This paper is the result of a research project called "Writing letters to teachers who made a difference: resonant memories and imaginaries as boost to (auto) formation?" It aims at problematizing the narrati- 
ves found in the letters which were written by Pedagogy first-year undergraduate students. Based on an epistolary nature as its empirical tool, a symbolic analysis was carried out in the light of theoretical/ methodological studies of the imaginary and of (auto)biographical studies of human development. Anchored in Josso (2002, 2010), Bachelard (1988, 1993), Durand (1988, 2008, 2012), Chevalier e Gheerbrant $(2015)$ e Eliade $(1977,1992,2013)$ the methodology used in this research was based on the research-formation and myth criticism from references built by Josso (2002), Delory-Momberguer (2008) and Durand (2012), respectively. The focus was to, in memories-references, search for the broadening of the idea of the teacher's-baptism, whose image emerged in the symbolic dimension of the letters under analysis.

Keywords: Initial teacher education. Epistolary Narratives. Imaginary. Education.

RESUMEN EL SIMBOLISMO DEL BAUTISMO CAPTURADO EN

\section{CARTAS PARA PROFESORES QUE DEJARON HUELLAS: LECTURAS ENTRECRUZADAS}

El presente trabajo es fruto del proyecto de investigación "Escritura de cartas a los profesores que dejaron huella: ¿memorias e imaginarios resonantes como catalizadores de la (auto)formación?" Tiene por objetivo problematizar las narrativas materializadas en las cartas, solicitadas a estudiantes en formación inicial en Pedagogía. Tomando la epístola como herramienta empírica, se utilizó el análisis simbólico a la luz de los estudios teórico-metodológicos del Imaginario y de los estudios (auto)biográficos de formación. Anclados en Josso (2002, 2010), Bachelard (1988, 1993), Durand (1988, 2008, 2012), Chevalier e Gheerbrant (2015) e Eliade (1977, 1992, 2013), la metodología utilizada en esta investigación se basa en la investigación-formación y mitocrítica, a partir de las referencias construidas por Josso (2002), Delory-Momberguer (2008) y Durand (2012), respectivamente. Nos enfocamos en buscar en los recuerdos-referencia, la amplificación de la noción de profesor-bautismo, cuya imagen emergió en la simbólica de las cartas analizadas.

Palabras clave: Formación inicial de profesores. Narrativas epistolares. Imaginario. Educación. 


\section{Considerações primeiras sobre a pesquisa...}

0 recorte que apresentamos neste artigo vincula-se à pesquisa Escrita de cartas aos professores que marcaram: memórias e imaginários ressonantes como fermentos de (auto) formação? Esta pesquisa emergiu a partir de nossas experiências como docentes, na interface entre questões metodológicas de ensino e de pesquisa, com base na pesquisa-formação, conforme utilizada por Josso $(2002 ; 2010)$ e Delory-Momberger (2008). Tal abordagem instiga possibilidades para problematizar questões relacionadas às histórias de vida, na vertente das autobiografias aprendentes, levando-nos a pensar nas seguintes questões epistemológicas: como as experiências da minha vida contribuem para os sentidos que dou àquilo que vivi? 0 que aconteceu para que eu viesse a ter as ideias que hoje tenho? Como cheguei até aqui?

Esta pesquisa resultou de uma prática que se assentou na abordagem (auto)biográfica e simbólica, tendo como objetivo apreender representações de professores vinculadas às trajetórias educativas, possibilitando-nos, através do trabalho com a memória de escolarização, socializar imagens-lembranças ensinantes e significativas, no contexto da formação do profissional.

Para dar conta da proposta, o estudo aproximou-se e dialogou com campos distintos da Educação, no âmbito da formação de professores e da formação de tecnólogos. Apostamos na construção de uma prática de pesquisa que permitiu, a partir do trabalho de coleta, a sistematização e a análise das cartas, para então identificarmos, através da escrita, a memória do professor do passado.

Com esta proposta, a pesquisa se coloca na tentativa de contribuir para o debate sobre memórias e trajetórias de formação, buscando evidenciar a força e o lugar ocupado pela memória e os reservatórios do imaginário como matérias férteis para processos de autoformação, bem como propulsoras da concretude das escolhas realizadas nas trajetórias de formação. Desta forma, mostrando que nem sempre importa o que fizeram de nós, mas o que fizemos com o que fizeram de nós, parafraseando Sartre (1946). Enfim, interessam-nos compreender as ressonâncias e as repercussões como movimentos cruciais no modo como cada um vai se formando e transformando-se na pessoa e profissional.

Como pesquisadores da área da educação, temos percebido que velhas fontes de pesquisa podem ser revisitadas a partir de outros pontos de vista. Neste caso, adotamos a carta como um gênero e também como uma fonte de pesquisa tematizada à luz dos estudos do imaginário e das histórias de vida, na perspectiva da pesquisa-formação, projeto e obra (JOSSO, 2002).

O gênero epistolar vem sendo estudado por historiadores da educação (FABRE, 1993; HÉBRARD, 2000; VIÑAO FRAGO, 1999; GASTAUD, 2009), onde a grande questão que se coloca é que:

Escrever cartas é uma prática em extinção. 0 ato de escrever cartas pessoais/intimas consiste em confrontar-se com códigos estabelecidos e, a partir deles, construir/inventar um lugar para si, através das palavras. Trocar cartas, corresponder-se, são formas de se expor, compartilhar experiências cotidianas e/ou profissionais e, muito especialmente, "pôr ordem em suas idéias, clarificar e recordar pensamentos, sensações e sentimentos'. (VIÑAO FRAGO, 1999, p. 127-128)

Abordar a escrita epistolar como fonte para os estudos das autobiografias aprendentes, relacionando-as aos estudos do imaginário, requer outros enfoques, releituras e reinterpretações. Nos estudos do imaginário, 
as cartas podem ser interpretadas a partir da linguagem simbólica, cuja modalidade se relaciona ao conhecimento indireto (DURAND, 1988) como um modo de captar o sensivel e a imaginação, num misto entre o que chamamos de real e imaginário ou real e ficção. Busca-se apresentar também uma das funções da imaginação, como fonte equilibradora psicossocial, e cuja narrativa epistolar abriu possibilidades de diálogo com a formação. Trata-se de uma formação que se inicia na sua intimidade e subjetividade, para se projetar no mundoda-vida através da abertura ao outro.

Outro aspecto do uso de cartas que, nesta pesquisa, denominamos de narrativa epistolar, diz respeito ao adentramento e ao aprofundamento em conteúdos subliminares passiveis de fazer "voltar à tona", na consciência, representações e valorizações de um reencontro singular-plural. A escrita, assim como um cheiro, uma imagem, uma cor, uma escultura, uma ornamentação, uma história, uma visita ou um sonho, pode desencadear uma série de imagens-lembranças (BACHELARD, 1993): ressonâncias e repercussões simbólicas.

As "ressonâncias" e "repercussões" são dois movimentos cruciais da análise fenomenológica: "as ressonâncias dispersam-se nos diferentes planos de nossa vida no mundo; a repercussão convida-nos a um aprofundamento de nossa existência" (BACHELARD, 1993, p. 3). Instaurou-se, assim, o jogo infinito das imagens, pelo qual aquele que escreve, lê, ouve, vê, percebe ou representa, dá prosseguimento à criação do criador em um estado intersubjetivo de imaginação aberta.

O gênero epistolar, revivido pela escrita de cartas a professores do passado, constituiuse em fonte e empiria. Isso por apostarmos que esta modalidade narrativa pode acionar imagens e representações nos reservatórios da memória, bem como movimentar os imaginários construídos ao longo da formação, que, ao fim e ao cabo, são depositários das imagens-lembrança e das recordações-referência. Tínhamos como questão de pesquisa que nos instigou, a saber, o seguinte: a escrita de cartas aos professores que nos marcaram no passado podem se constituir em fermentos de (auto)formação? Nossa questão nos antecipava uma possivel resposta, advinda do campo teórico ao qual nos filiamos, qual seja: a narrativa pode ser autoformadora na exata medida em que possibilita a reapropriação e a reflexão sobre o vivido, tendo no imaginário o lugar mental de imagens guardadas e produzidas, ao longo do trajeto pessoal e antropológico. Portanto, apostamos, sim, que a escrita de cartas ao passado pode se tornar um fermento do processo autoformador.

No processo, foi solicitado a alunos de três instituições de ensino superior, que elaborassem cartas para professores do passado, que tiveram alguma importância na vida destes alunos: "professores que marcaram". Assim, a partir de uma questão detonadora -“Qual o professor que me marcou? - solicitou-se a tarefa, em sala de aula, onde foi pedido a cada sujeito que escrevesse para professores que o marcaram, positiva ou negativamente, no decurso de sua trajetória de formação, deixando em aberto, para o estudante, escolher se o professor que o marcou foi da educação infantil ou foi aquele com quem teve aulas, no semestre anterior, pois o que une as instituições mobilizadas nesta pesquisa é: "como" foi essa marca e não "quando" ocorreu essa marca.

Um aspecto que vale ressaltar, expresso por esta pesquisa, é justamente a tônica da formação docente, tratada a partir da pergunta desencadeadora das cartas: Qual o professor que me marcou? Fosse uma marca que alavancasse o desejo de querer ser aquele professor ou não. Essa possibilidade reflexiva de trazer à tona este pensar traz para o campo da formação as vivências desses alunos que, neste 
momento, a partir da reflexão feita na escrita, transformam essas vivências em experiências.

O conceito de experiência é tratado como central às histórias de vida, ao ser definido, por Josso, como “[...] associando a sua componente factual e circunstancial à sua componente compreensiva [...] articula o processo de formação e o processo de conhecimento num círculo retroactivo [...]" (2002, p. 55). A transformação de uma vivência em experiência inicia-se no momento em que nós prestamos atenção ao que se passa em nós e/ou na situação na qual estamos implicados, seja a escrita de uma carta, de uma tese, uma narrativa oral, entre outras inúmeras possibilidades e situações, nas quais nossa atenção consciente é de algum modo solicitada. Este é o primeiro momento de tomada de consciência, seguido de uma atividade mental do tipo intelectual que procura dar sentido ao que se passou. É, pois, nesta "não relação imediata" a um acontecimento, interior ou exterior, na sua classificação conceitual e na sua atribuição de sentido, que se pode constituir a experiência propriamente dita (JOSSO, 2002, p. 54).

Cabe ressaltar que tomamos a ideia de experiência consoante ao processo de biografização, tal como proposto por Delory-Momberger (2016). A autora trabalha este conceito como um "[...] conjunto de operações e de comportamentos pelos quais os indivíduos trabalham para darem-se uma forma própria em que se reconhecem e são reconhecidos pelos outros [...]" (2016, p. 4). A construção desse processo, passa por diversos níveis de elaboração da experiência.

Corroboramos com esta autora, quando reflete sobre a importância de nossas fontes experienciais, que não são construídas, apenas, com base em experiências pessoais e originais, mas enraizadas no social. Tais fontes são transmitidas sob a forma de regras de compor- tamento e de saberes professados por adultos (pais e professores), bem como por instituições socializadoras. Neste sentido, a autora reflete que o mundo do humano poderia ser definido pela capacidade de transmitir e de se apropriar cumulativamente de experiências sempre novas, e, então, de se transformar por si mesmo. Todavia a maneira como a experiência é colocada em sentido, pelo narrador, e, por outro lado, como ele deve estar atento para perceber como ela é recebida, interpretada e apropriada (ou não) pelo outro, pode fazer uma diferença exponencial quanto à apreensão dessa experiência. De algum modo, a escrita das cartas para professores que marcaram pode ser vista como uma interpretação da experiência dos sentidos sobre a marca daquele professor, na futura profissão que é também ser professor,

Nesta perspectiva, o gênero epistolar também objetivou potencializar o sentido da heterobiografia, “[...] nomear as formas de experiência e escrita de si que praticamos quando compreendemos a narrativa e o relato da experiência do outro, quando nos apropriamos dessa narrativa no sentido de compreendermos a nós mesmos [...]" (DELORY-MOMBERGER, 2016 , p. 8). Somente posso reconstruir o meu mundo de experiência da narrativa quando relaciono esse mundo a minhas fontes prévias e construtos biográficos e os compreendo na relação dinâmica de ressonância e inteligibilidade de minhas experiências (DELORY-MOMBERGER, 2016).

Quando a experiência é apreendida em uma história, neste caso, em uma carta, é precisamente nesta trama que acontece a sua transmissão e apropriação. Neste sentido, encontra-se aqui a dimensão da subjetividade. Com certeza não é possível colocar, no mesmo patamar de construção da experiência, a experiência vivida e a experiência contada, esta última uma representação construída da 
primeira. A experiência contada revela uma interpretação em que se evidencia o aspecto tridimensional da temporalidade em ação, em que o passado, presente e futuro se realocam, pois o passado, que é reinterpretado/contado na narrativa, que está no presente, redimensiona o futuro.

Neste sentido, na abordagem (auto)biográfica de Josso (2010) sobre os relatos de vida fundados nas lembranças são uma reconstrução de fatos reais (ou reinventados), interpretando o passado, em função do momento presente, e projetando as perspectivas futuras. São vivências que, pensadas e trabalhadas, podem vir-a-ser experiências autoformadoras. A questão que se coloca refere-se à temporalidade vivida no passado, revisitada no presente, com vistas a projetar o futuro. Assim, estas reconstruções, enquanto narrativas escritas, baseadas em fatos reais, apelam à imaginação de cada um, tentando dar sentido à experiência patente, que seria o nível do imaginário, trazendo a trama em si do relato e podendo remeter a um relato arquetípico, segundo a encenação dos personagens, da persona do autor e de seus projetos evocados nas cartas.

Logo, podemos dizer que as "recordações -referência" são simbólicas e orientadoras de uma vida, aquilo que "o autor compreende como elementos constitutivos de sua formação" (JOSSO, 2002, p. 29), abrangendo uma dimensão concreta, visivel, que apela para nossas percepções ou imagens sociais, e uma dimensão invisivel, que apela para nossas emoções, sentimentos, sentidos ou valores. Neste sentido, as recordações-referência podem ser qualificadas de experiência formadora, porque o que foi apreendido serve, daí para a frente, como referência a inúmeras situações do gênero, como um acontecimento existencial único e decisivo na simbólica orientadora de uma vida.

\section{A pesquisa como se deu...}

A metodologia utilizada nesta investigação, tanto no resgate como no tratamento das narrativas auto(biográficas), está fundamentada nas correntes teórico-metodológicas denominadas pesquisa-formação e mitocrítica, basicamente a partir dos referenciais construídos por Josso (2002), Delorry-Momberguer (2008) e Durand (1979), respectivamente.

A proposta de Josso (2002), de se perceber o processo de investigação como um "Caminhar para si" (JOSSO, 2010) denota sucessão inconclusa do processo de formação, remetendo a nossa própria trajetória de vida neste mundo. Nesta perspectiva da pesquisa-formação, a autora nos brinda com o conceito de "caminhar para si", afirmando que:

O processo do caminhar para si apresenta-se, assim, como um projeto a ser construído no decorrer de uma vida, cuja atualização consciente passa, em primeiro lugar, pelo projeto de conhecimento daquilo que somos, pensamos, fazemos, valorizamos e desejamos na nossa relação conosco, com os outros e com o ambiente humano e natural. (JOSSO, 2010, p. 59)

É por meio da palavra e da escrita que a atividade de rememoração se institui. 0 sujeito, envolvido na pesquisa, não apenas revela seus sentidos e representações, como também encontra a oportunidade de indagar a si próprio sobre o tema em questão por ele vivido. A questão de pesquisa faz disparar, no indagado, memórias e imagens-lembranças que de algum modo ressoam e repercutem na tomada de consciência para, neste caso, escrever sobre as marcas positivas e negativas do professor ou professora que o marcou no decurso de sua trajetória de formação.

Nosso intuito de propor uma questão aberta, em torno do mundo das experiências vividas, é reforçado por Delory-Momberger (2008, p. 25), quando diz: “como se encontram o mun- 
do de experiências, figuras e expectativas que a criança, o jovem e o adulto em formação trazem consigo, e o mundo de conhecimentos que as instituições educativas propõem?" Em outras palavras: como o sujeito pensa que a escola, através do professor ou da professora e da sociedade elaboraram modelos e trajetórias de formação? Nessa perspectiva, percebemos o biográfico "como uma categoria da experiência que permite ao indivíduo, nas condições de sua inscrição sócio-histórica, integrar, estruturar, interpretar as situações e os acontecimentos vividos" (DELORY-MOMBERGER, 2008, p. 26).

No entanto, a autora nos alerta, e é importante ressaltarmos aqui, que essas experiências que compõem o mosaico das biografias humanas não são, de forma alguma, experiências individuais e espontâneas. Elas:

[...] trazem a marca de sua inscrição histórica e cultural e têm origem nos modelos de figuração narrativa e nas formas de relação do indivíduo consigo mesmo e com a coletividade, elaborados pelas sociedades nas quais se inscrevem [...]. (DELORY-MOMBERGER, 2008, p. 27)

É, portanto, dessa forma que percebemos e tratamos as narrativas epistolares nesta pesquisa. Além disso, somaremos a "mitocrítica" (DURAND, 1979), tipo de análise que consiste em retomar o modelo metodológico da Psicocrítica, de Charles Mauron (1962), que construiu este método com o intuito de fazer uma garimpagem das metáforas obsessivas, por meio de grupos de imagens que se repetiam na vida singular, com o sentido de buscar uma pregnância simbólica ${ }^{1}$ que representasse semanti-

1 O objeto da simbólica não é uma coisa analisável, mas uma fisionomia, uma espécie de modelagem, expressiva, viva, das coisas mortas, inertes. Essa impotência constitutiva que leva o pensamento a jamais poder intuir objetivamente uma coisa, mas a integrá-la imediatamente em um sentido, Cassirer a chama de pregnância simbólica. Neste sentido, na consciência camente o sentido daquela narrativa epistolar. No caso desta pesquisa, olharemos os traços míticos (ARAÚJO; BAPTISTA, 2003) subsumidos na escrita das cartas, a partir da abordagem mitocrítica. Ou seja, buscar no patente o que estava latente, usando uma lupa analítica para ampliar as imagens, pois “[...] mesmo quando os traços míticos não são tão visiveis, eles estão lá, pela simples razão de que um mito não desaparece, apenas se esconde [...]" (ARAÚJO; ARAÚJO, 2008, p. 72).

Organizamo-nos metodologicamente com os seguintes passos:

1. identificação das repetições significativas sobre as marcas dos professores ou professoras, que chamaremos de atividades matriciais;

2. nucleamento de um banco de dados sobre representações, imagens e imaginários presentes nas narrativas epistolares sobre professores que marcaram a vida dos estudantes;

3. estabelecimento de relações entre as marcas dos professores e os valores assumidos na escolha profissional.

Houve momentos coletivos de análise deste material no GEPIEM (Grupo de Ensino Pesquisa sobre Imaginário Educação e Memória), onde a pesquisa se originou e se desenvolveu, como também momentos individuais, em que o pesquisador esteve in loco com os sujeitos da pesquisa.

Inicialmente, construímos uma planilha para capturar elementos de análise, com o intuito de mapear as imagens presentes na escrita das cartas. Exemplificamos, a seguir, com os dados dos sujeitos:

humana, nada é apresentado, mas tudo é reapresentado. (DURAND, 1988, p. 58) 
Figura 1 - Planilha das marcas positivas e negativas

\begin{tabular}{|l|l|}
\hline Marcas positivas & Marcas negativas \\
\hline Carinho / afeto & $\begin{array}{l}\text { Baixa autoestima / } \\
\text { humilhação } \\
\text { Menosprezo }\end{array}$ \\
\hline Inspiração & $\begin{array}{l}\text { Incompetência e falta de } \\
\text { tato }\end{array}$ \\
\hline Admiração & Mágoa / ressentimento \\
\hline Confiança & \\
\hline Segurança & \\
\hline Competência & \\
\hline Cuidado & \\
\hline Dados Aleatórios & \\
\hline
\end{tabular}

Figura 2 - Planilha de marcas: alunos FaE/UFPel

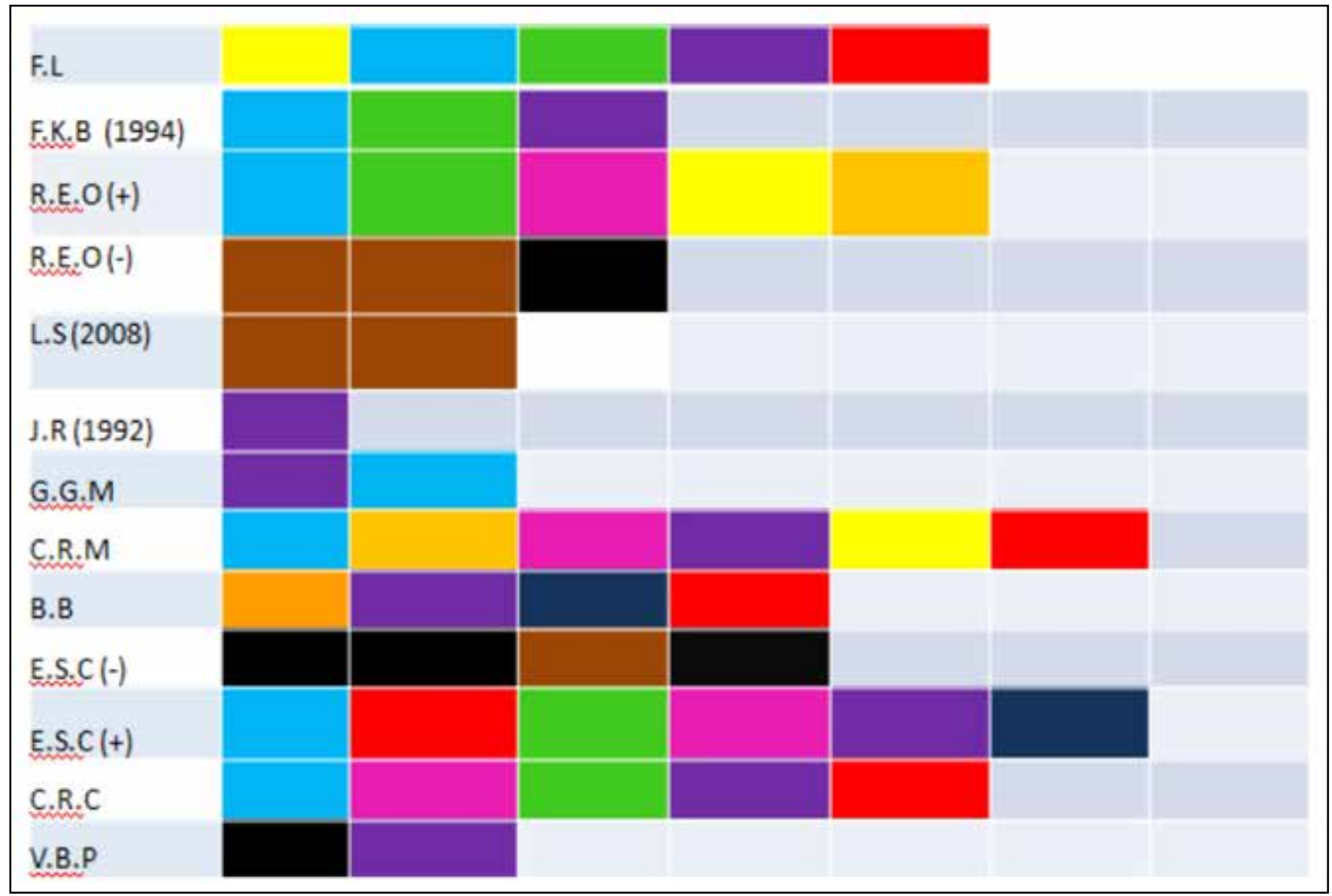


Figura 3 - Planilha de marcas: alunos UERGS

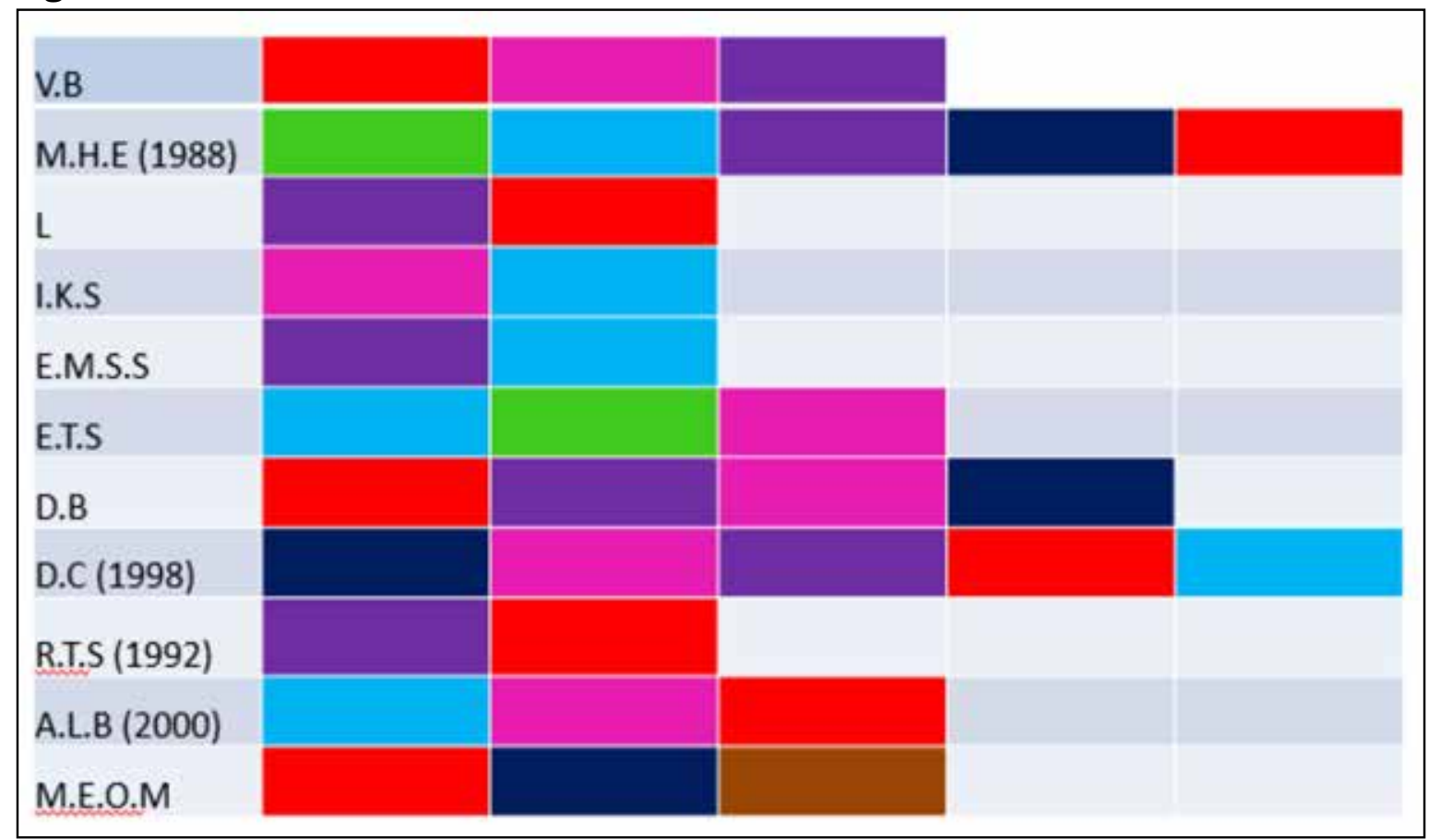

Figura 4 - Planilha de marcas: alunos IFSul

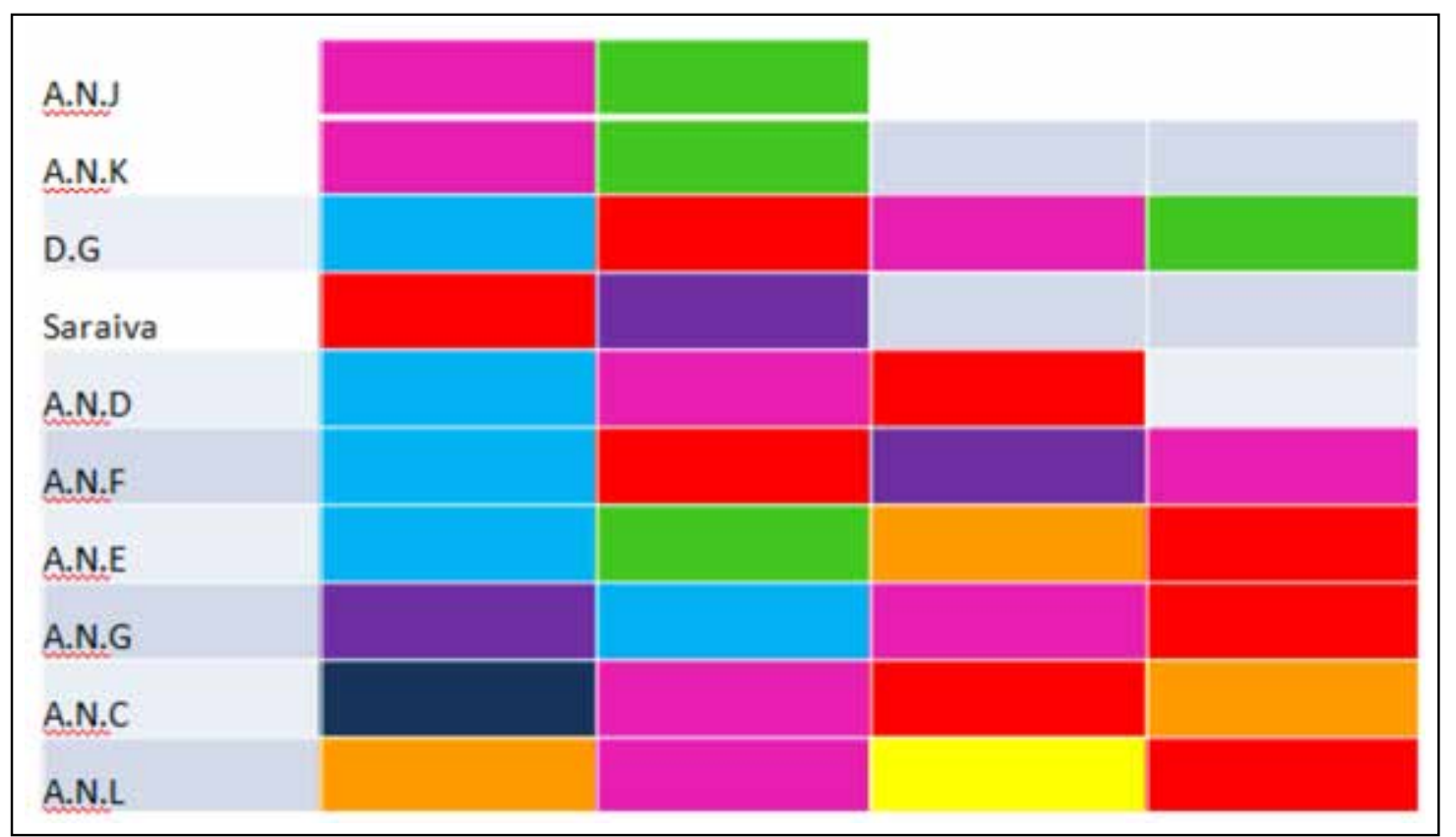

Após esta etapa de mapeamento dos elementos (sentidos) contidos nas cartas, entramos num detalhamento mais aprofundado de cada um deles, a seguir exemplificados na tabela e na descrição densa de cada instituição, em suas pregnâncias simbólicas referentes a cada escrita.

Elencamos, portanto, o quadro de referência da UFPEL/FaE (Universidade Federal de Pelotas/Faculdade de Educação), configurando-se nosso recorte de análise, neste artigo. 


\section{UFPel/Fae}

\begin{tabular}{|c|c|c|c|c|c|c|}
\hline Identificação & Sexo & Idade & $\begin{array}{l}\text { Área / Curso } \\
\text { de formação }\end{array}$ & Núcleos significantes & Núcleo de sentidos & $\begin{array}{l}\text { Convergência } \\
\text { simbólica } \\
\text { pregnante } \\
\text { (mitema) }\end{array}$ \\
\hline V.B.P & $\mathrm{F}$ & $\begin{array}{l}\text { De } 20 \\
\text { a } 30 \\
\text { anos }\end{array}$ & $\begin{array}{l}\text { Formação } \\
\text { docente em } \\
\text { Pedagogia }\end{array}$ & $\begin{array}{l}\text { "Mesmo com os diversos } \\
\text { problemas, agradeço pelo } \\
\text { ensino que me destes, } \\
\text { foi fundamental para eu } \\
\text { chegar onde eu estou" }\end{array}$ & $\begin{array}{l}\text { Menosprezo e } \\
\text { inspiração }\end{array}$ & Professor-batismo \\
\hline F.L & $\mathrm{F}$ & $\begin{array}{l}\text { De } 20 \\
\text { a } 30 \\
\text { anos }\end{array}$ & $\begin{array}{l}\text { Formação } \\
\text { docente em } \\
\text { Pedagogia }\end{array}$ & $\begin{array}{l}\text { "As vivências contribuíram } \\
\text { para a minha formação, não } \\
\text { só como aluna, mas como a } \\
\text { profissional que almejo ser" }\end{array}$ & $\begin{array}{l}\text { Confiança; } \\
\text { Carinho; } \\
\text { Cuidado; } \\
\text { Inspiraçãa e } \\
\text { admiração }\end{array}$ & Professor-batismo \\
\hline R.E.O & $\mathrm{F}$ & $\begin{array}{l}\text { De } 20 \\
\text { a } 30 \\
\text { anos }\end{array}$ & $\begin{array}{l}\text { Formação } \\
\text { docente em } \\
\text { Pedagogia }\end{array}$ & $\begin{array}{l}\text { "A senhora sempre me } \\
\text { aconselhou, tirou minhas } \\
\text { dúvidas sem hesitar" }\end{array}$ & $\begin{array}{l}\text { Carinho; } \\
\text { Cuidado; } \\
\text { Competência; } \\
\text { confiança e } \\
\text { segurança }\end{array}$ & Professor-anjo \\
\hline $\begin{array}{l}\text { R.E.0 } \\
\text { (professor ruim) }\end{array}$ & $\mathrm{F}$ & $\begin{array}{l}\text { De } 20 \\
\text { a } 30 \\
\text { anos }\end{array}$ & $\begin{array}{l}\text { Formação } \\
\text { docente em } \\
\text { Pedagogia }\end{array}$ & $\begin{array}{l}\text { "Venho lhe dizer o quanto } \\
\text { suas aulas mal dadas me } \\
\text { prejudicaram..." }\end{array}$ & $\begin{array}{l}\text { Baixa autoestima; } \\
\text { incompetência e } \\
\text { menosprezo. }\end{array}$ & $\begin{array}{l}\text { Professor- } \\
\text { monstro }\end{array}$ \\
\hline J.R & $\mathrm{F}$ & $\begin{array}{l}\text { De } 20 \\
\text { a } 30 \\
\text { anos }\end{array}$ & $\begin{array}{l}\text { Formação } \\
\text { docente em } \\
\text { Pedagogia }\end{array}$ & $\begin{array}{l}\text { "A senhora foi } \\
\text { fundamental para a } \\
\text { formação da minha } \\
\text { personalidade" }\end{array}$ & Inspiração & Professor-batismo \\
\hline C.R.M & $\mathrm{F}$ & $\begin{array}{l}\text { De } 20 \\
\text { a } 30 \\
\text { anos }\end{array}$ & $\begin{array}{l}\text { Formação } \\
\text { docente em } \\
\text { Pedagogia }\end{array}$ & $\begin{array}{l}\text { "A senhora, com um } \\
\text { enorme sorriso me } \\
\text { dizia que eu deveria ser } \\
\text { professora" }\end{array}$ & $\begin{array}{l}\text { Carinho, confiança, } \\
\text { competência, } \\
\text { inspiração, } \\
\text { segurança e } \\
\text { admiração }\end{array}$ & Professor-anjo \\
\hline F.K.B & $\mathrm{F}$ & $\begin{array}{l}\text { De } 20 \\
\text { a } 30 \\
\text { anos }\end{array}$ & $\begin{array}{l}\text { Formação } \\
\text { docente em } \\
\text { Pedagogia }\end{array}$ & $\begin{array}{l}\text { "A maneira como me } \\
\text { tratava, fez com que eu, } \\
\text { desde criança, tivesse o } \\
\text { sonho de ser professora" }\end{array}$ & $\begin{array}{l}\text { Carinho; } \\
\text { Cuidado e inspiração }\end{array}$ & $\begin{array}{l}\text { Professor-batismo } \\
\text { ou } \\
\text { Professor- } \\
\text { horizonte }\end{array}$ \\
\hline B.B & $\mathrm{F}$ & $\begin{array}{l}\text { De } 20 \\
\text { a } 30 \\
\text { anos }\end{array}$ & $\begin{array}{l}\text { Formação } \\
\text { docente em } \\
\text { Pedagogia }\end{array}$ & $\begin{array}{l}\text { "Eu, com certeza, nunca } \\
\text { deixarei de lhe citar } \\
\text { quando o assunto for ‘a } \\
\text { melhor professora”" }\end{array}$ & $\begin{array}{l}\text { Confiança; } \\
\text { inspiração; } \\
\text { admiração e dados } \\
\text { aleatórios }\end{array}$ & $\begin{array}{l}\text { Professor- } \\
\text { horizonte }\end{array}$ \\
\hline L.S & $\mathrm{F}$ & $\begin{array}{l}\text { De } 20 \\
\text { a } 30 \\
\text { anos }\end{array}$ & $\begin{array}{l}\text { Formação } \\
\text { docente em } \\
\text { Pedagogia }\end{array}$ & $\begin{array}{l}\text { "Agora que estou } \\
\text { estudando para ser } \\
\text { professora, vejo o quão } \\
\text { diferente poderia ter sido } \\
\text { suas aulas" }\end{array}$ & Humilhação & $\begin{array}{l}\text { Professor- } \\
\text { monstro }\end{array}$ \\
\hline C.R.C & $\mathrm{F}$ & $\begin{array}{l}\text { De } 20 \\
\text { a } 30 \\
\text { anos }\end{array}$ & $\begin{array}{l}\text { Formação } \\
\text { docente em } \\
\text { Pedagogia }\end{array}$ & $\begin{array}{l}\text { "Quero ser igual a você } \\
\text { dentro de sala de aula, } \\
\text { para tratar todos iguais, } \\
\text { para ver a felicidade } \\
\text { todos os dias no rosto dos } \\
\text { pequenos" }\end{array}$ & $\begin{array}{l}\text { Carinho; } \\
\text { competência; } \\
\text { cuidado e admiração }\end{array}$ & Professor-anjo \\
\hline G.G.M & M & $\begin{array}{l}\text { De } 20 \\
\text { a } 30 \\
\text { anos }\end{array}$ & $\begin{array}{l}\text { Formação } \\
\text { docente em } \\
\text { Pedagogia }\end{array}$ & $\begin{array}{l}\text { "Por tua causa eu vou ser } \\
\text { professor" }\end{array}$ & Carinho e inspiração & $\begin{array}{l}\text { Professor- } \\
\text { horizonte }\end{array}$ \\
\hline $\begin{array}{l}\text { E.S.C } \\
\text { (professor ruim) }\end{array}$ & $\mathrm{F}$ & $\begin{array}{l}\text { De } 20 \\
\text { a } 30 \\
\text { anos }\end{array}$ & $\begin{array}{l}\text { Formação } \\
\text { docente em } \\
\text { Pedagogia }\end{array}$ & $\begin{array}{l}\text { "Jamais repetirei seus atos } \\
\text { quando eu for exercer meu } \\
\text { papel de professora" }\end{array}$ & $\begin{array}{l}\text { Baixa autoestima; } \\
\text { menosprezo; } \\
\text { mágoa e } \\
\text { ressentimento. }\end{array}$ & $\begin{array}{l}\text { Professor- } \\
\text { monstro }\end{array}$ \\
\hline $\begin{array}{l}\text { E.S.C } \\
\text { (professor bom) }\end{array}$ & $\mathrm{F}$ & $\begin{array}{l}\text { De } 20 \\
\text { a } 30 \\
\text { anos }\end{array}$ & $\begin{array}{l}\text { Formação } \\
\text { docente em } \\
\text { Pedagogia }\end{array}$ & $\begin{array}{l}\text { "Fostes uma professora } \\
\text { que livrou uma criança de } \\
\text { uma constante aflição" }\end{array}$ & $\begin{array}{l}\text { Carinho; } \\
\text { admiração; cuidado; } \\
\text { competência e } \\
\text { admiração. }\end{array}$ & Professor- anjo \\
\hline
\end{tabular}

Quadro 1 - Pregnâncias simbólicas de todas as cartas analisadas da UFPEL 
A seguir, fizemos uma descrição dos sujeitos e procedimentos. Os sujeitos estão cursando Pedagogia, na sua maioria do sexo feminino - 12 são mulheres e apenas 1 é homem, estes se encontram na faixa etária entre $18 \mathrm{e}$ 30 anos; cursavam o 1o semestre do curso de Pedagogia, no turno diurno, quando escreveram as cartas, no ano de 2014.

Das 13 cartas sorteadas, apenas três versam sobre o professor ruim, e exaltam o quanto faltava atenção da parte do professor para com os alunos, e que se sentiam humilhadas e desprezadas por ele, pois, para ser professor, é preciso ter dedicação e competência, e o dever de tratar a todos de forma igualitária. As outras 10 cartas são de agradecimentos e homenagens para os professores que tiveram ao longo da sua trajetória escolar. Expressam o quão dedicados foram, a importância que tinham, pela forma que eram tratados, pelo carinho e a segurança que transmitiam, ao entrarem em sala de aula; os alunos não mediram esforços para falar bem do professor que mais os marcou, e da admiração por ele.

Os mitemas encontrados dizem respeito ao pequeno tema que emerge simbolicamen- te das narrativas escritas que está investido de realidades instauradoras e fundantes. Ou seja, de possibilidades para uma interpretação aberta, através das figuras simbólicas que emergiram aos olhos do pesquisador. De acordo com os estudos de Peres (1999), da teoria de Gilbert Durand (2012), um mitema é a menor unidade de sentido de uma narrativa mítica e, por isso, simbólica. Na Universidade Federal de Pelotas, no curso de Pedagogia, encontramos quatro mitemas: Professor -batismo, Professor-anjo, Professor-monstro, Professor-horizonte.

Neste artigo, analisaremos o recorte de quatro (4) cartas pertencente a um dos grupos envolvidos na pesquisa. A escolha dessas cartas deu-se pela convergência simbólica pregnante, resultando no professor-batismo. Os participantes eram estudantes do curso de Pedagogia (diurno), em sua maioria do sexo feminino - doze (12) mulheres e apenas um (1) homem, ${ }^{2}$ na faixa etária entre dezoito (18) e trinta (30) anos, quando escreveram as cartas, no ano de 2014. A seguir, exemplificamos as pregnâncias simbólicas referentes às escritas elencadas do professor-batismo.

\section{Faculdade de Educação - Curso de Pedagogia}

\begin{tabular}{|c|c|c|c|}
\hline Nome & Núcleos significantes & Núcleo de sentidos & $\begin{array}{l}\text { Convergência } \\
\text { simbólica pregnante }\end{array}$ \\
\hline V.B.P & $\begin{array}{l}\text { "Mesmo com os diversos problemas, agradeço pelo } \\
\text { ensino que me destes, foi fundamental para eu chegar } \\
\text { onde eu estou" }\end{array}$ & $\begin{array}{l}\text { Menosprezo e } \\
\text { inspiração }\end{array}$ & Professor-batismo \\
\hline F.L & $\begin{array}{l}\text { "As vivências contribuíram para a minha formação, não só } \\
\text { como aluna, mas como a profissional que almejo ser" }\end{array}$ & $\begin{array}{l}\text { Confiança; Carinho; } \\
\text { Cuidado; Inspiração; } \\
\text { admiração }\end{array}$ & Professor-batismo \\
\hline J.R & $\begin{array}{l}\text { "A senhora foi fundamental para a formação da minha } \\
\text { personalidade" }\end{array}$ & Inspiração & Professor-batismo \\
\hline F.K.B & $\begin{array}{l}\text { "A maneira como me tratava, fez com que eu, desde } \\
\text { criança, tivesse o sonho de ser professora" }\end{array}$ & $\begin{array}{l}\text { Carinho; Cuidado e } \\
\text { inspiração }\end{array}$ & Professor-batismo \\
\hline
\end{tabular}

Quadro 2 - Pregnâncias simbólicas das quatro cartas analisadas

As convergências simbólicas encontradas nestas narrativas epistolares estão baseadas na realidade de cada uma. Como uma possibi-
2 É interessante ressaltar que não houve um recorte específico do montante de alunos, neste caso. O número expressivo de alunas explica-se por um movimento comum ao curso de Pedagogia, onde a maioria dos matriculados é do sexo feminino. 
lidade de enxergar para além do que está dito, como um conhecimento indireto (DURAND, 1988), fizemos um exercício de devaneio, buscando ressonâncias e repercussões simbólicas que convergissem para uma Imagem Simbólica que viesse a resumir, hermeticamente, as potências semânticas contidas no texto. A reunião destes dados culminou numa pregnânica simbólica, que está em evidência neste artigo, sendo ela uma representação instauradora, emergente das cartas. Este conteúdo estava patente no texto, nas linhas e seus espaços, e tinha sua raiz no latente, ou seja, no que foi substantivado por esta imagem. A partir dessa substantivação, fizemos o exercício de encontrar, um traço mítico, ${ }^{3}$ sendo que desta análise emergiu um sentido "batismal", que culminou na imagem simbólica do professor-batismo.

A teoria do imaginário (DURAND, 2012) tramita na concomitância entre os seguintes aspectos: os gestos do corpo, nossa motricidade primária; os centros nervosos; o inconsciente e as representações simbólicas. Integrando toda a psique, no seio de uma única atividade - a fantástica transcendental. ${ }^{4} \mathrm{O}$ trajeto antropoló-

3 "O mito conta uma história sagrada; ele relata um acontecimento ocorrido no tempo primordial, o tempo fabuloso do 'princípio'. Em outros termos, o mito narra como, graças às façanhas dos Entes Sobrenaturais, uma realidade passou a existir, seja uma realidade total, o Cosmo, ou apenas um fragmento: uma ilha, uma espécie vegetal, um comportamento humano, uma instituição. É sempre, portanto, a narrativa de uma 'criação': ele relata de que modo algo foi produzido e começou a ser". (ELIADE, 2013, p. 11)

4 Nos estudos de Gilbert Durand (referência deste texto e, amplamente citado), encontramos o conceito de transcendentalidade da consciência imaginante que é independente, em grande parte, dos conteúdos acidentais da percepção empírica. A essa imaginação, que excede os limites do mundo sensivel, o autor nomina de "fantástica transcendental". Ou seja, de acordo com ele, a transcendentalidade da imaginação impede o determinismo, seja do arquétipo, seja do meio sociocultural. A imaginação, neste caso, tem uma "liberdade soberana". Segundo Durand (2012, p. 404-405): "O sentido supremo da função fantástica. Erguida contra o destino mortal, é assim o eufemismo. O que quer dizer que há no Homem um poder de melhoria do mundo. Mas essa melhoria não é a vã especulação "objetiva", uma vez que a realidade emerge ao seu nível é a criação, a transformação do mundo gico é esse movimento que oscila num vai e vem contínuo entre as raízes inatas da representação sapiens e as intimações variadas do meio cósmico e social. Esta é a lei sistêmica, a trajetória que está sempre em movimento. Este teórico postula a gênese recíproca do gesto pulsional ao ambiente ecológico e social, e vice-versa.

A partir da noção de trajeto antropológico, Durand enuncia as estruturas antropológicas do imaginário. Entendendo a ideia de estrutura não como um fechamento teórico, mas um "dinamismo transformador" (DURAND, 2012, p. 63). A ideia de estrutura implica numa dinâmica sujeita a transformações, "quando as formas deixam o domínio da troca mecânica para passar ao uso semântico, quando o estruturalismo aceita uma vez por todas ser figurativo" (DURAND, 2012, p. 16). Este autor define estrutura como "uma forma transformável, desempenhando o papel de protocolo motivador para todo um agrupamento de imagens e suscetivel ela própria de se agrupar numa estrutura mais geral que chamaremos de Regime" (DURAND, 2012, p.64).

o "regime" é uma bipartição que Durand (2012) faz das estruturas do imaginário a partir de três dominantes reflexas: dominante postural "exige as matérias luminosas, visuais e as técnicas de separação, de purificação, de que as armas, as flechas, os gládios são símbolos frequentes" (DURAND, 2012, p. 54); dominante digestiva "implica as matérias da profundidade, a água ou a terra cavernosa suscita os utensílios continentes, as taças e os cofres, e faz tender para os devaneios técnicos da bebida e do alimento" (DURAND, 2012, p. 54) e dominante copulativa "projetam-se nos ritmos sazonais e no seu cortejo astral, anexando todos os substitutos técnicos do ciclo: a roda e a roca de fiar, a vasilha onde se bate manteiga e o isqueiro, e, por fim, sobredeterminam toda a fricção tecnológica pela rítmica sexual" (DURAND, 2012, p. 54-55).

da morte e das coisas no da assimilação à verdade e à vida". 
A partir da tripartição gestual, tem-se a bipartição estrutural em regimes de imagens diurno e noturno. 0 diurno refere-se, por exemplo, à relação do bem contra o mal, à imaginação heroica. Sua estrutura figurativa é a heroica, seu reflexo dominante é o postural, os esquemas verbais de distinção são os de: separar/misturar, subir/cair, e os arquétipos substantivos: luz/trevas, céu/inferno.

O noturno conta com duas estruturas figurativas. A mística, seu reflexo dominante é o digestivo, possui um regime intimista, confusional, de união, profundo, calmo, quente, como símbolo indo de encontro ao sintema ${ }^{5}$ do ventre, da taça, do leite, do mel, do vinho. $\mathrm{O}$ destino não é combatido, é assimilado. E a outra estrutura figurativa, a sintética ou dramática, com seu reflexo dominante copulativo e seus derivados rítmicos, seu esquema verbal de reunir, os arquétipos substantivos, por exemplo, o fogo, o germe e a árvore, como o símbolo indo de encontro ao sintema: a orgia, o messias, o sacrifício.

Os dados simbólicos bipolares são um vasto sistema de equilíbrio antagonista, no qual a imaginação simbólica aparece como um sistema de forças de coesão antagonistas. As imagens simbólicas equilibram-se, umas e outras, mais ou menos sutilmente, conforme a coesão das sociedades e, também, conforme o grau de integração dos indivíduos nos grupos (DURAND, 1988, p. 92).

O conhecimento indireto resgata a sacralidade daquilo que há muito nos distanciamos, o que para Durand (2008) se refere ao conhecimento do homem da tradição, sendo este um conhecimento uno, sua consciência sistematizada, em que as coisas - pensadas ou simbólicas - têm um sentido, contêm uma qualidade

5 Sintema é "uma imagem que tem por função, antes de mais nada, um reconhecimento social, uma segregação convencional". Poder-se-ia dizer que há aí um símbolo reduzido à sua potência sociológica. (DURAND, 1988, p. 33) escondida que não pode ser visualizada pelo pensamento direto (perceptivo ou racional), ao passo que o saber da cultura ocidental está cortado pela extroversão, pela fragmentação e pela divisão do Homem e do objeto.

0 autor faz uma reflexão acerca deste tipo de conhecimento, ao mostrar que as bases do conhecimento do homem ocidental estão alicerçadas na unidade vazia do cogito; no primado do pensamento lógico como sinônimo da única via do conhecimento, em detrimento das demais modalidades do pensar humano.

Um conceito importante para a reflexão que iremos propor é o que entendemos como imaginário (DURAND, 1988). Como a obra deste autor nos mostra, o imaginário é um elemento constitutivo e instaurador do comportamento específico do homo sapiens, visto que é por meio do imaginário que nos reconhecemos como humanos, conhecemos o outro e aprendemos as realidades múltiplas do mundo. Podemos dizer que o imaginário, enquanto fundamento das concepções e das representações do humano, constitui-se numa espécie de substância primordial fomentada pelas inter - relações e pelas intimações advindas do meio onde estamos inseridos. Ao mesmo tempo, ele é real, está presente em nosso cotidiano. As nossas ações são decorrentes da força de um imaginário, como também as nossas ações reforçam o imaginário de uma dada cultura.

Neste sentido nos propomos a analisar estas cartas, na perspectiva do conhecimento indireto (DURAND, 2008), aqui semanticamente representadas pela imagem do professor-batismo, como uma imagem fermentadora de sentido para pensar sobre os professores que marcaram a trajetória destas acadêmicas do curso de Pedagogia. ${ }^{6}$

6 A pesquisa foi realizada com estudantes de ambos os sexos. Para este artigo, visto termos escolhido o mitema do professor-batismo, foram analisadas cartas de estudantes mulheres. 


\section{Do batismo}

Parece-nos que a primeira imagem que temos do batismo parte de um dos quatro elementos naturais: ar, terra, fogo e água. É deste último que falamos. A água está no ápice de relevância para o imaginário religioso, já que esta preexiste a Terra, segundo o Gênesis: "as trevas cobriam a superficie do abismo, e o Espírito de Deus planava sobre as águas". Eis o que Eliade nos traz do simbolismo aquático:

As águas simbolizam a soma universal das virtualidades: são fons et origo, o reservatório de todas as possibilidades de existência; precedem toda forma e sustentam toda criação. Uma das imagens exemplares da Criação é a Ilha que subitamente se 'manifesta' no meio das vagas. Em contrapartida, a imersão na água simboliza a regressão ao pré-formal, a reintegração no modo indiferenciado da preexistência. (1992, p. 65).

Por outro lado, Durand traz o aspecto sombrio da água como um símbolo nictomorfo7 "a água, além de bebida, foi o primeiro espelho dormente e sombrio" (2012, p. 95). A embarcação mortuária de alguns povos ou, então, o medo da água, embebida pelos terrores da noite, é como um convite direto a morrer, um convite à viagem sem retorno. A partir deste símbolo da água hostil, da água turva, da água enegrecida, percebemos a fragilidade das classificações simbólicas que se orientam puramente por referências objetivas, mais uma vez mostramos o quanto o conhecimento indireto, concernente à pluralidade da alma e do sentir humano, pode transformar o símbolo da pureza, da clarividência, da transformação pelo rito do batismo para um caráter fatal, como

7 O símbolo nictomorfo corresponde aos símbolos relacionados ao medo diante da fuga do tempo, como uma grande epifania imaginária da angústia humana, estes símbolos "são animados pelo esquema heraclitiano da água que corre ou de cuja profundidade, pelo seu negrume, nos escapa [...]. Esta água negra é sempre no fim das contas, o sangue, o mistério do sangue que corre nas veias ou se escapa com a vida pela ferida, cujo aspecto menstrual vem ainda sobredeterminar a valorização temporal". (DURAND, 2012, p. 111) uma epifania da desgraça do tempo, como reforçou o pintor Salvador Dalí, ao representar em sua obra o derretimento temporal com os "relógios moles" que escorrem como água. ${ }^{8}$ Assim, em uma perspectiva de transformação da vida, de um novo nascimento, a imersão nas águas pode resultar na dissolução das formas, levando o imerso a um estado primevo - ou seja, este mergulho repete o gesto cosmogônico da manifestação formal. Tal movimento proporciona um estado de morte, acompanhada de uma súbita e nova vida, com a emersão, dando às águas o simbolismo de renascimento. O contato com este elemento é, portanto, regenerativo: tanto pelo segundo nascimento, quanto pela fertilidade que ela sobeja. Portanto, o batismo corresponde a uma cosmogonia aquática, porém:

[...] tanto no plano cosmológico como no plano antropológico, a imersão nas Águas equivale não a uma extinção definitiva, e sim a uma reintegração passageira no indistinto, seguida de uma criação, de uma nova vida ou de um 'homem novo', conforme se trate de um momento cósmico, biológico ou soteriológico. Do ponto de vista da estrutura, o 'dilúvio' é comparável ao 'batismo', e a libação funerária às lustrações dos recém-nascidos ou aos banhos rituais primaveris que trazem saúde e fertilidade. (ELIADE, 1992, p. 65)

Vale comentar a respeito da cultura judaico-cristã que preconizou a simbolismo do batismo na cultura ocidental. o banho ritual judaico era feito em conexão com o ritual de purificação, no judaísmo, e, no cristianismo, o vocábulo batismo insere-se a partir da pessoa de João Batista. A limpeza exigida pela lei mosaica tinha de repetir-se sempre que o crente se tornasse impuro. Isso não acontecia com o

8 A Persistência da Memória é o tema desta obra de 1931 de Salvador Dalí. A pintura está localizada na coleção do Museu de Arte Moderna (MoMA) de Nova lorque, desde 1934. É amplamente reconhecida e frequentemente referenciada na cultura popular, como o fizemos aqui. 
batismo que João Batista realizava nem com o praticado mais tarde pelos cristãos. 0 batismo de João Batista indicava arrependimento e rejeição do anterior modo de vida, na passagem para uma nova vida, um Homem novo. O batismo cristão simboliza o fato de que a pessoa escolheu se dedicar a Deus; ela faz isso apenas uma vez, e não repetidamente. Nesta perspectiva, apesar da divergência entre os batismos, já referida, a herança simbólica que trazemos da base judaico-cristã redobra a verdadeira matriz arquetípica do ritual do batismo, dado que é o nivel verbal que desenha a matriz arquetípica, o atributo de ambos está subentendido pelos verbos imergir, emergir e purificar.

No Dicionário de símbolos, Chevalier e Gheerbrant (2015), quando tratam do vocábulo batismo, trazem a pessoa de João Batista e relegam a ele a denominação de batismo por imersão, existentes até hoje, e também o caracterizam como um rito de purificação e renovação. Com o mesmo intuito, outras religiões utilizaram as águas na imersão sacra dos Homens (no sentido antropológico do termo). Contudo, as matizes iniciática e escatológica estariam prenhes no rito de João Batista, dado o seu sentido único (que não se repete).

Há dois gestos incutidos no rito batismal do qual nos ocupamos: a imersão e a emersão. A primeira conota o desaparecimento do ser pecaminoso, que, em sua vida ordinária, nutre os mais diversos pesares não sacros, identificados como proibidores da ascensão ao sagrado, ou seja, que impossibilitam o fenômeno religare. Não se trata de "esconder-se da face divina", mas, sim, de desaparecer "diluir-se", por meio da imersão nas águas. Essa diluição é fecunda, pois trará à tona um novo Ser. Neste movimento, de "queda amparada", o batizado deixa sua roupagem cotidiana, e não tarda em mudar sua própria natureza, sendo, então, transformado. Passa de um estado a outro com dois gestos: queda e ascensão.
A emersão é o segundo gesto, que traz a bênção da renovação. Aquele que se batiza não é maturado pelo rito, mas sim morto e renascido. Eis uma nova criatura, provinda do que foi, porém, ainda mais, do que se propôs (relação íntima com a crença na mudança). $\mathrm{Na}$ subida, percebe-se a marca da diferença e da novidade, bem como as sensações de esterilidade e recomeço. Rompe-se com o estado passado, na prospecção do futuro.

O batismo, tradicionalmente lido, está atrelado aos ritos religiosos e pode ocorrer por decisão própria ou compulsória, pelos pais ou pelas autoridades que se ocupam de atos desta natureza, como podemos analisar em culturas distintas. Porém, a simbólica do rito terá a mesma funcionalidade, e, por isso, "validade". Ratifica-se o recomeço batismal tendo os elementos necessários para isso: aquele que cumpre o rito, o rito, e aquele que recebe o rito.

Podemos perceber a emersão dos seres sem o mergulhar dos mesmos. Os dilúvios são exemplo representativo desta simbólica, e nem sempre são destrutivos. A lua e sua gravidade podem ser vistas como gestos batismais, que atraem os mares, os quais abraçam e inundam a terra, em movimentos cíclicos que movimentam todo o globo. o encharcar das costas e sua fertilização também se revela numa enchente escura que traz as faces da mortalha. Porém, após sua recolha (emersão), percebe-se a vida, a nova vida que renasce das águas - em movimentos que podem ser entendidos como o rito em si. A terra, adubada pelos nutrientes da emersão, personifica-se naquele que participa do rito. ${ }^{9}$ E a circularidade deste ritual (repe-

9 "Nalguns mitos, um dilúvio assinala ciclicamente o fim de intervalos de tempo imensos. As águas não têm forma em si, mas dão nascimento a múltiplas formas que, uma vez separadas da origem, são vulneráveis ao envelhecimento, à mudança e ao decaimento e que têm de ser renovadas com o tempo; assim, o dilúvio representa a ablução cósmica e um recomeço. (ELIADE, 2012). Cada inundação anual do Nilo, no antigo Egipto, era uma repetição do momento da criação 
tição que rompe o escatológico), ratifica uma natureza mítica.

O valor apodíctico do mito é periodicamente reconfirmado pelos rituais. A rememoração e a reatualização do evento primordial ajudam o homem 'primitivo' a distinguir e reter o real. Graças à repetição contínua de um gesto paradigmático, algo se revela como fixo e duradouro no fluxo universal. Através da repetição periódica do que foi feito in illo tempore, impõe-se a certeza de que algo existe de uma maneira absoluta. Esse 'algo' é 'sagrado', ou seja, transumano e transmundano, mas acessivel à experiência humana. A 'realidade' se desvenda e se deixa construir a partir de um nivel 'transcendente', mas de um 'transcendente' que pode ser vivido ritualmente e que acaba por fazer parte integrante da vida humana. (ELIADE, 2013, p. 124)

Lembramos aqui o poder do rito, que se potencializa pela repetição dos gestos, das sacras palavras que, então (re)feito inúmeras vezes, comunica o mito ou seu motivo. Neste espaço, a criatura se vê n'outro tempo e espaço. Ritualizada, a criatura é forçada a despir-se do mundo concreto, sendo lançada no mundo dos deuses e dos heróis. Neste contexto, o Homem pode abandonar suas dúvidas ou seus medos, na esfera mundana, de que, no rito (e pelo rito), ele se ausenta. E esta segurança só é firmada pois o que ele fará já foi feito. o processo já é conhecido, e tocou homens e mulheres de todas as idades históricas. No rito do batismo, por milênios, homens e mulheres mudaram a sua natureza, frente aos gestos daqueles que guardavam a magia, o saber, a memória. Logo, não nos aventuramos no repetir do ritual, apenas seguimos o exemplo vivo, conduta arquetipal imemoriável.

\section{Da análise das cartas, um professor-batismo emerge}

mas também relembrava as água originais do nada “a partir das quais emergiu a matéria mas nas quais o mundo está suspenso em delicado equilíbrio". (MARTIN, 2012, p. 50)
Não podendo figurar a infigurável transcendência, a imagem simbólica é transfiguração de uma representação concreta através de um sentido para sempre abstrato. 0 símbolo é, portanto, uma representação que faz aparecer um sentido secreto; ele é a epifania de um mistério. (DURAND, 1988, p. 15)

É comum, para os pesquisadores que carregam a tocha da teoria durandiana, a utilização dos verbos: emergir, desvelar, surgir, aparecer, entre outros similares. Isso se explica pelo fato das inferências de análise estarem, em primeiro lugar, submetidas às potencialidades simbólicas dos próprios dados. No caso do símbolo, podemos dizer que há duas metades em sua composição. O significante, sendo ele a parte visível, tomado de concretude, ${ }^{10} \mathrm{e}$ o significado, que é concebível, porém não é representável.

Podemos notar, no Quadro 2, na segunda coluna (Núcleo de Significantes), exemplos de trechos onde a palavra e o texto estão dados. 0 escrito é concreto e carrega consigo o contexto do sujeito, suas percepções do real, a memória e, por fim, a capacidade imaginativa/criadora para esboçar (em letras - palavras - frases texto) correlações do tema sugerido (questão de pesquisa) a sua própria trajetória de vida.

O núcleo de significantes limita-se na sua própria elucidação. Porém, em conjunto com seus núcleos de sentidos (terceira coluna do mesmo quadro), oferecem ao pesquisador um campo vasto de análise. Campo onde brotam imagens simbólicas, justamente pela pregnância de símbolos, expressa na repetição, na composição das frases, ideias etc. Contudo,

10 “[...] todo o símbolo autêntico possui três dimensões concretas: ele é, ao mesmo tempo, 'cósmico' (ou seja, retira toda a sua figuração do mundo sensível que nos rodeia); 'onírico' (enraíza-se nas lembranças, nos gestos que emergem em nossos sonhos e constituem, como bem mostrou Freud, a massa concreta de nossa biografia mais íntima); e, finalmente, 'poético', ou seja, o símbolo também apela para a linguagem, e a linguagem mais impetuosa, portanto, a mais concreta. (DURAND, 1988, p. 16) 
trata-se da repetição de núcleos semânticos, e não meramente de palavras, pois "é através do poder de repetir que o símbolo ultrapassa indefinidamente sua inadequação fundamental. Mas essa repetição não é tautológica: ela é aperfeiçoadora através das aproximações acumuladas" (DURAND, 1988, p. 17). Este movimento pode ser visto como circular, ou em uma solenoide, onde os objetos revisitam, a todo o instante, um centro. Este centro é o nucleamento, que reverbera numa imagem simbólica, investida, então, desta redundância aperfeiçoadora.

Vejamos os casos. O sujeito V. B. P. redige uma carta ao seu professor marcante. De todo o texto, ressaltamos um trecho que resume a pregnância: "Mesmo com os diversos problemas, agradeço pelo ensino que me destes, foi fundamental para eu chegar onde eu estou". Eis o núcleo de significantes (dado concreto), o qual se soma aos sentidos, que neste caso (com base em todo o conteúdo da carta) trouxe a ideia de "menosprezo" e "inspiração". Pode-se inferir que este professor, no decorrer do contato que teve com seu aluno, não veio a servir de exemplo profissional. Mesmo não tendo uma relação "positiva" (redutoramente falando) com seu aluno, o professor o atinge de maneira que o inspira. 0 aluno tem consciência da marca de seu professor, tanto que diz ser fundamental em seu trajeto formativo. Esta marca, preconizada pela a forma que este professor lidou com seu aluno (gestos), pode ser considerada um traço batismal, já que foi por meio desta que a mudança de "estado" se fez presente no Ser.

Em consonância, verificamos que a experiência que fere, repetida e inúmeras vezes, ou não (uma única experiência pode, por si só, abarcar repetições simbólicas e dar potência ao único ato, reverberando marcas), transforma o sujeito. 0 rito (conjunto de gestos, falas, hábitos, neste caso), provavelmente tenha sido amargo, dada a aparição dos "diversos problemas". Contudo, faz parte do rito a prova, ou o sofrimento. Chevalier e Gheerbrant (2015) trazem a simbólica do fogo, como elemento batismal, ao passo que queima/fere/mata para o renascimento de algo puro e/ou regenerado. Seria o fogo, então, agente de um mesmo processo, como a água (primeira ou virgem, hoje simbolizada na água-benta). Contudo, o fogo viria depois da imersão nas águas, estás, sim, receptoras e provocadoras de dores e sofrimento (em analogia à relação do professor -aluno então expostos). Para exemplificar, os autores trazem uma passagem de João Batista, ao falar do fogo, a propósito do batismo:

Eu na verdade vos batizo em água para vos trazer a penitência: porém o que há de vir depois de mim é mais poderoso do que eu, e eu não sou digno de the levar a sandália. Ele vos batizará no Espírito Santo, e em fogo (Mateus, 3, 11). E os exegetas observarão que o fogo, meio de santificação menos material e mais eficaz do que a água, já no Antigo Testamento simboliza a intervenção soberana de Deus e de seu Espírito a purificar as consciências. (Isaías, 1, 25)

E eu farei passar esta terceira parte pelo fogo,e eu os queimarei como se queima a prata:e os provarei como se prova o ouro. (Zacarias, 13, 9). (CHEVALIER; GHEERBRANT, 2015, p. 126)

O martírio seria um batismo de fogo, e é confirmado pela marca (lembrança) deixada no batizado. Porém, a imersão do sujeito é sempre positiva (visto seu movimento ascensional). O Ser é grato pelo seu novo estado, e rememora o rito como importante para sua mutação. Eis um princípio interior de aperfeiçoamento, que explode sentidos, a partir do traço mítico do batismo.

No caso do sujeito F. L., temos o seguinte núcleo de significantes: "As vivências contribuíram para a minha formação, não só como aluna, mas como a profissional que almejo ser". Esta afirmação soma-se ao núcleo de sentidos que emergiram, tais como: "confiança", "cari- 
nho", “cuidado", “inspiração" e "admiração". Na soma destes dois núcleos, fica clara a ideia de que o professor agiu de forma a ser seguido, como guia e modelo. 0 sujeito explicita que a vivência contribui para a sua formação, durante e postumamente, reconhecendo a marca deixada pelo profissional. Logo, as vivências podem ser aqui vistas, metaforicamente, como o banho nas águas sacras, as quais revigoram o espírito, alimentam a alma e propulsionam - Ser a uma nova aventura. Esta emersão ritual remonta ao tempo antigo, e até mesmo as divindades (principalmente femininas e materializadas em estatuetas) eram mergulhadas em meio aquático para sua purificação:

O mesmo mecanismo ritual da regeneração pelas águas explica a imersão das estátuas das divindades, no mundo antigo. 0 ritual do banho sagrado era praticado habitualmente no culto das grandes deusas da fecundidade e da agricultura. As forças exaustas da divindade eram deste modo reintegrado, assegurando uma boa colheita (a magia da imersão provocava a chuva) e a fecunda multiplicação dos bens. (ELIADE, 1977, p. 239)

Portanto, o traço batismal também pode ser visível na vivência, na reunião dos tempos que, somados, configuram um único rito, regenerativo. Há, desta maneira, os três elementos necessários ao batismo: quem confere o rito (professor), o próprio rito (suas atitudes exemplares, reverberantes na inspiração do aluno) e o batizado (neste caso, o sujeito F. L.). Os casos seguintes também são exemplos de marcas positivas de professores do passado.

J. R. traz o seguinte núcleo de significantes: "A senhora foi fundamental para a formação da minha personalidade". Expressão forte, que transborda a potência simbólica, fruto da vivência do estudante na relação com a professora. Assim como os outros casos, a personalidade do sujeito está condicionada à passagem do mestre pela vida do aprendiz. O segundo núcleo polarizou-se num único sentido: “inspiração". De maneira consciente e breve, sem demasia sentimental, J. R. reconhece na "senhora", ferramenta e obra, a forja de sua identidade. Repete-se a metáfora anterior, onde a vivência do sujeito pode ser análoga ao contato com a água batismal (atitudes da professora).

Porém, toda relação nutrida por ambos, o conhecimento passado, o compartilhamento de valores etc., não corresponde a uma cena cotidiana, mesmo que parta do cotidiano. Essa repetição de atos, que transborda numa valoração da professora pelo aluno, é incomum, pois fere no aluno a marca de um aprendizado que o conscientiza sobre a importância da relação no processo formativo. Assim, a capacidade de interferir na vida do outro, positivamente, só é possivel dada a especialidade do momento em aula. 0 aluno banha-se numa fonte limpa, águas ritualizadas com o propósito de regenerá-lo. Tal fonte alimenta a possibilidade de (trans)formação. Por isso, há uma ruptura com um passado, no presente, pois se ignora aquilo que poderia ter sido, e se aceita o que foi.

O último caso, F. K. B. traz o seguinte núcleo significante: "A maneira como me tratava, fez com que eu, desde criança, tivesse o sonho de ser professora". Percebe-se aqui um espaço temporal maior. A repetição dos gestos (na maneira de tratamento) catalisou no sujeito o sonho de ser, um dia, mestre. Este alvorecer do desejo ocorre justamente na aurora da formação do aluno, o que acrescenta potencialidade às redundâncias simbólicas, transmitidas em sala de aula, embaladas em casa, no sonhar das noites. Ainda, neste exemplo, temos o seguinte núcleo de sentidos: "carinho", "cuidado" e "inspiração", que trazem a noção de aconchego e zelo, propulsores da inspiração que ganha asas, também, com o exemplo. 
O batismo, como dissemos, prevê a mudança de estado. A partir dele, o humano transforma-se. Passa, pela imersão, por uma prova, onde vem a despir-se de toda a roupagem mundana que um dia carregou, torna-se apto a um novo futuro. Neste caso, "querer ser professora" é o fruto da transformação, o novo estado pós-emersão.

\section{Algumas reflexões à guisa de conclusão}

Em todos os casos, o rito batismal pode ser percebido na transformação do sujeito, via uma marca (seja ela positiva ou negativa, numa análise redutora), onde a imersão e a emersão são também visiveis. A imersão dá-se pela troca cotidiana entre o professor e o aluno e na interferência, do primeiro, na vida real do segundo. Como dito, há o desapego na imersão, daquilo que um dia o sujeito poderia vir a ser, na aceitação daquilo que se constituiu com o rito.

$\mathrm{Na}$ emersão, os sujeitos reconhecem sua sina, num novo contexto/estado. Passam a ter uma função específica no mundo, ou se reconhecem nele, com o auxílio da diferença e no delineamento de uma identidade. No exemplo do que capturamos nas cartas, pela via simbólica, o professor coabita o imaginário.

Desse modo, convém lembrar que este tipo de leitura e abordagem enriquece o campo de produção acadêmica das histórias de vida em

\section{Referências}

ARAÚJO, Alberto Filipe; BAPTISTA, Fernando Paulo. Variações sobre o imaginário: domínios, teorizações, práticas hermenêuticas. Lisboa: Instituto Piaget, 2003. ; ARAÚJO, Joaquim Machado. Imaginário e educação: da criança mitológica e da modelação do humano. In: BARROS, João de Deus. (Org.). Imaginário e educação: pesquisas e reflexões. São Luis: EDUFMA, 2008. p. 20- 42. (Coleção Diálogos Contemporâneos).

BACHELARD, Gaston. A poética do devaneio. Tradu- formação aliadas às contribuições dos estudos do imaginário, em especial no que se refere ao simbolismo, mostrando que é possivel tecer outras leituras no campo da Educação. Sobretudo, mostra o forte potencial da tecedura entre campos teóricos e metodológicos do imaginário e da abordagem das histórias de vida e processos (auto)biográficos, em especial. Soma-se e integra-se ao campo da formação de professores a urdidura da escrita de si, de caráter autobiográfico, como uma emergência da experiência que permite ao indivíduo, nas condições de sua inscrição no mundo profissional, integrar, estruturar, interpretar as situações e os acontecimentos vividos.

Por fim, cabe dizer que a abordagem simbólica dos estudos do imaginário enriquece e amplifica a palavra e a escrita de si, através da rememoração que se explicita. O sujeito, envolvido na pesquisa via a escrita de cartas ao passado, não apenas revela seus sentidos e representações, como também encontra a oportunidade de indagar a si próprio sobre o tema em questão por ele vivido. A questão de pesquisa faz disparar, no indagado, memórias, imagens-lembranças e recordações-referência que, de algum modo, ressoam e repercutem na tomada de consciência para, neste caso, escrever sobre as marcas positivas e negativas do professor ou professora que o marcou no decurso da sua trajetória de formação.

ção de Antônio de Pádua Danesi. 2. ed. São Paulo: Martins Fontes, 1988.

A poética do espaço. Tradução de Antônio de Pádua Danesi. São Paulo: Martins Fontes. 1993.

CHEVALIER, Jean; GHEERBRANT, Alain. Dicionário de símbolos. Tradução de Vera da Costa e Silva, Raul de Sá Barbosa, Angela Melim e Lúcia Melim. 2. ed. Rio de Janeiro: José Olympio, 2015. 
DELORY-MOMBERGER, Christine. Biografia e educação: figuras do indivíduo-projeto. Tradução de Maria da Conceição Passeggi, João Gomes da Silva Neto e Luis Passeggi. Natal: EDUfRN; São Paulo: Paulus, 2008.

. Construção e transmissão da experiência nos processos de aprendizagem e de formação. In: ABRAHÃO, M. H., FRIZON, L. H. B.; BARREIRO, C. B. (Orgs.). A nova aventura (auto)biográfica. Tomo I. Porto Alegre: EDUPUCRS, 2016. p. 39-57.

DURAND, Gilbert. Figures mythiques et visages de l'oeuvre. De la mythocritique à la mythanalyse. Paris, Berg International, 1979.

A imaginação simbólica. Tradução de Eliane Fittipaldi Pereira. São Paulo: Cultrix,1988.

Ciência do homem e tradição.

Tradução de Lúcia Pereira de Souza. São Paulo: TRIOM, 2008.

As estruturas antropológicas do

imaginário. Tradução de Hélder Godinho. São Paulo: Martins Fontes, 2012.

ELIADE, Mircea. Tratado de história das religiões. Tradução de Natália Nunes e Fernando Tomaz. Lisboa: Edições Cosmos, 1977.

O sagrado e o profano. Tradução de Rogério Fernandes. São Paulo: Martins Fontes, 1992. Mito e realidade. Tradução de Pao-

la Civelli. São Paulo: Perspectiva, 2013.

FABRE, Daniel. (Org.). Écritures ordinaires. Paris: Centre Georges Pompidou, 1993.

GASTAUD, Carla Rodrigues. De correspondências e correspondentes: cultura escrita e práticas epistolares no Brasil entre 1890 e 1950. 2009. 246f. Tese (Doutorado em Educação) - Faculdade de Educação, Programa de Pós-Graduação em Educação, Universidade Federal do Rio Grande do Sul, Porto Alegre, 2009.

HÉBRARD, Jean. Por uma bibliografia material das escrituras ordinárias. A escritura pessoal e seus suportes. In: MIGNOT, A. C. V. et al. (Orgs.). Refúgios do eu. Educação, História, Escrita Autobiográfica. Florianópolis: Mulheres, 2000. p. 29-61.

JOSSO, Mari-Christine. Experiências de vida e formação. Tradução de José Cláudio e Júlia Ferreira. Lisboa: EDUCA, 2002.

Caminhar para si. Tradução de

Albino Pozzer; Coordenado por Maria Helena Menna Barreto Abrahão. Porto Alegre: EDIPUCRS, 2010.

A imaginação e suas formas em ação nos relatos de vida e no trabalho autobiográfico: uma perspectiva biográfica como suporte de conscientização das ficções verossímeis com valor heurístico que agem em nossas vidas. In: PERES, Lucia Maria Vaz et al. (Org). Essas coisas do imaginário. São Leopoldo: Oikos; Brasília: Líber Livro, 2009. p. $118-147$

MARTIN, Kathleen. 0 livro dos símbolos. Reflexões sobre imagens arquetípicas. Colônia: TASCHEN, 2012.

MAURON, Charles. Des méthaphores obsédantes au mythe personnel: introduction à la Psychocritique. Paris: José Corti, 1962.

PERES, Lúcia Maria Vaz. Dos saberes pessoais à visibilidade de uma Pedagogia Simbólica. 154f. Tese (Doutorado em Educação) - Faculdade de Educação, Universidade Federal do Rio Grande do Sul, Porto Alegre, 1999.

Narrativas epistolares como uma abordagem teórico metodológica: escrita de carta a professores do passado como ressonâncias e repercussões. In: FONTOURA, Helena Amaral de.; LELIS, Isabel Alice Oswald Monteiro; CHAVES, Iduina Mont'Alverne. (Orgs,). Espaços formativos, memórias, narrativas. Curitiba: Editora CRV, 2014. p. 173-186.

SARTRE, J., O Existencialismo é um Humanismo, 1946. Disponivel em: <https://pensador.uol.com.br/ frase/MjUyOTU/>. Acesso em: 03 nov. 2016.

VIÑAO FRAGO, Antonio. Leer y escribir. Historia de dos prácticas culturales. México: Fundación Voces y Vuelos, 1999.

Recebido em: 30.09.2016

Aprovado em: 20.11.2016 
Lúcia Maria Vaz Peres é professora titular da Faculdade de Educação na Universidade Federal de Pelotas (UFPel). Doutora em Educação, pela Universidade Federal do Rio Grande do Sul, e Líder do Grupo de Estudos e Pesquisa sobre Imaginário, Educação e Memória (GEPIEM). e-mail: Ip2709@gmail.com.

Almirante Tamandaré, 225, Pelotas, Rio Grande do Sul/RS, CEP: 96010-750

Alexandre da Silva Borges é mestrando no Programa de Pós-Graduação em Educação da Universidade Federal de Pelotas (UFPel), membro do Grupo de Estudos e Pesquisa sobre Imaginário, Educação e Memória (GEPIEM). e-mail: alexandreborgesh@gmail.com.

Corredor das Cruzeiras, 1953, Povo Novo, Rio Grande do Sul/RS, CEP: 96224-000

Luciana Martins Teixeira Lindner é doutoranda no Programa de Pós-Graduação em Educação da Universidade Federal de Pelotas (UFPel), membro do Grupo de Estudos e Pesquisa sobre Imaginário, Educação e Memória (GEPIEM). e-mail: lucianateixeira@unipampa.edu.br.

Rua Carlos Mangabeira, 102, apto. 503, Centro, Bagé, Rio Grande do Sul/RS, CEP: 96400.490 